\title{
CUSTOMERS' PERCEPTION ON PROMOTION AND PRICE RELATED TO BUYING DECISION (A CASE STUDY AT PT GARUDA INDONESIA)
}

\author{
Mustika Sari ${ }^{1,}$ Deslida Saidah ${ }^{2}$, Rr. Endang Wahyuni ${ }^{3}$,Luth Mafrudhoh ${ }^{4}$ \\ 1. STMT Trisakti, 2. STMT Trisakti, 3. STMT Trisakti, 4. STMT Trisakti \\ $\bowtie$ corresponding author: mustika0017@gmail.com
}

\begin{abstract}
The purpose of this research is to find out the customers' perception about the relationship between promotion and price with buying decision. The research was done at PT Garuda Indonesia in 2015. In analyzing data, the authors used quantitative method, by employingmultiple regression technique. The research data were gathered through spreading Likert scale questionnaires to 40 people. , The instrument was tested with validity and reliability test before being spread to the respondents.

The results show that the value of $r$ for $X_{1}$ is 0.588 which means there is a medium relationship between variables $\mathrm{X}_{1}$ and $\mathrm{Y}$, variable $\mathrm{X}_{2}$ of 0.639 illustrates there is a positive and strong relationship to $\mathrm{Y}$ variable. Promotion and Price have a strong relationship with the decision to buy with an $F$ value of 18,686 . The value of $R_{2}$ is $50.3 \%$ means that variation of buying decision can be explained from promotion and price $50.3 \%$ while the other $49.7 \%$ is determined by other factor. The result of this research is that buying decision is related to promotion effort and price either by itself (partial) or together (stimulant).
\end{abstract}

Keywords : Promotion, Price, Buying Decision, Correlation and Regression

\section{Introduction}

PT Garuda Indonesia has been the largest state-owned airline company since its establishment in 1949. Until 2015 the company has a total fleet of 175 aircraft units with 40 domestic destinations and 36 international destination routes with domestic market share up to 2015 by $44 \%$ and $28 \%$ of international market share. PT Garuda Indonesia is not free from internal and external problems, such as the demands of cabin crew, safety demand in aviation, airline complaints and airline price wars. Tight competition urges PT Garuda Indonesia to be able to offer attractive possibility, and determine the right promotion to make customer decide to use its services.

A previous research revealed that the phenomenon of price war in the business 
of aviation services today actually makes Garuda Indonesia take steps out of the crowd by improving the quality of service, and not involve in the price war. The study analyzed factors that could potentially affect consumer buying interest (Diana PuspitaSari, 2006). The strategy used was by prioritizing the competitive and comparative advantages of the company so that people can distinguish between the qualities of service of PT Garuda to other airlines. In addition, the safety factor and service quality were always highlighted to convince the public to fly with Garuda Indonesia. More importantly, the timeliness of departure accompanied by increased fleet increase the comfort of passengers.

In addition to providing services, PT Garuda Indonesia also conducts the introduction of products delivered to the public. It is done through a planned and structured promotion in which one of them is cooperating with travel agents by creating tour packages and conduct promotional activities by holding trade fairs on a regular basis both in the country and outside representatives' country. With the exhibition, customers will get to know the products offered. No matter how good a product or a service is, if it is not heard and is not beneficial to the consumer, it will never be used or bought. Supported by previous journals Kuntjoroadi \& Safitri, (2009) said, that Garuda has a competitive positioning among its competitors in the aviation services industry in Indonesia. Conditions and preconditions in the concept of sustainable competitive advantage (SCA ) are needed to be applied as Garuda's marketing strategy, and whether SCA can be used as Garuda's marketing strategy to challenge the competition in the aviation services industry in Indonesia.

Also said by (Yoo, Donthu, n.d.), these dimensions are then related to brand equity. The empirical tests using a structural equation model support the research hypotheses. The results show that frequent price promotions, such as price deals, are related to low brand equity; whereas high advertising spending, 
high spending, high price, good store image and high distribution intensity are related to high brand equity. The problem of the research is how the promotion and price can influence the buying decision. The promotion in this case is how the company can promote its program, how promotional programs in a company can influence buying decisions, and the price.

Promotion has been defined as the coordination of all seller efforts to set up channels of information and persuasion in order to sell goods and service or promote an idea. The indicators to determine the promotion are Advertising, Sales Promotion, Events and Activities, Publicity, Direct Marketing (Belch george \& Michael, 2009). While Tjiptono Fandy (2011), argues price is the exchange value of product benefits (for consumers and for producers) which are generally expressed in monetary units. While Kotler \& Keller (2008) argues the price is "The value consumers exchanged for a benefit on the consumption use or possession of goods or services." (Simamora Bilson, 2011), defines the notion of sales as: "Stimulates immediate purchases or more products by consumers or business buyers". The sales concept is a sales-oriented (internal) concept, in which the market assumes that the consumer must be influenced in order to increase sales, so as to achieve maximum profit as the company's goal (Singgih Santoso, 2004).

Perception is the view has been accepted by consumers. It is possible that consumer perception about service are different from reality because consumers do not know all facts that exist or have been wrong. Perception of service is very influenced by the process in providing services and also the results of providing services. Perception is a process where one can choose, organize and interpretation information into a very meaningful image in the world (Linawati, 2015).

Marketing is the process of defining, anticipating, creating, and fulfilling the needs and desires of consumers of products and services. There are 7 (seven) main marketing functions that are consumer analysis, product / service sales, 
pricing, distribution, and marketing research, and opportunity analysis (David, 2011).

When demand and load factors are high, revenue management techniques will be very valuable in allowing airlines to gain maximum benefit from favourable market conditions. The decision in applying a revenue management technique also considers the competition among airlines. Some passengers have a very high 'willingness-to-pay' such as corporate business travellers. Airline should find a way of charging them a near-to-maximum price they will accept. Growing passenger resentment at high airfares will attract new entrants to the market especially LCC (Shaw, 2011).

The research from Haryono said that price give contribution to customer satisfaction, and also the quality of services can give customer satisfaction (Haryono, Wahyuni endang, 2016).

And from (Rahmawati, 2015) said that Garuda should socialization of its new aircraft operation that can build the perception of public and airlines users in order to understand the superiority of new aircraft and to provide a number seats in economy class for promotion price to build the public perception that the price of Garuda Indonesia ticket is in conformity with the purchase power Indonesia consumers.

\section{Method}

This type of research used quantitative research methods using associative research that aimed to determine whether there was a relationship between different variables (Sugiyono, 2009). The population of this study was 40 Garuda customers, from incidential respondents. Before the instrument was used to retrieve data, the instrumentwas tested first with validity and reliability test (Sanusi Anwar, 2011). Data were analyzed by using correlation test techniques, simple Pearson product moment ( $\mathrm{r}$ ) correlation, $\mathrm{t}$ test and $\mathrm{F}$ test. 


\section{Result and Discussion}

The result of promotion validity test, price and buying decision which have 20 point statement valid with significant level 5\% obtained value of Promotion in 0.977, Price in 0.978 , and buying decision equals to 0.947 .

\section{Customer Perception of Promotion to Buying Decision ( $\left.\mathrm{X}_{1}\right)$}

The simple correlation test of regression equation formed is $\mathrm{Y}=1,322+$ $0,630 X_{1}$.

If promotion variable is increased to 1 then buying will be 1,952 . If the promotion increase is done until the optimal condition or ideal that is on the scale of 5 on each instrument questionnaire so that obtained a score of $5 \times 20=$ 100 it will get a buying decision of $Y=1,322+0,630(100)=64,322$. The correlation of Pearson product moment $(\mathrm{r})$ indicates the correlation of $\mathrm{Y}$ to $\mathrm{X}_{1}$ is 0.588 indicating that there is a positive correlation between Promotion $\left(\mathrm{X}_{1}\right)$ with Buying decision $(\mathrm{Y})$. The determinant correlation coefficient $\left(\mathrm{R}^{2}\right)$ is 0.346 or $34.6 \%$. This means that the variant that occurs in the decision variable buy $34,6 \%$ is determined by the variant that occurs in the promotion variable. While the remaining $65,4 \%$ is determined by other factors. Test Result that is equal to 4,486 with probability significance 0,001 . It is known that $\mathrm{t}$ table $(\mathrm{df}=$ $40, a ́=0,05)$ is 1.684 .

\section{Customer Perception of Price to Buying Decision ( $\left.\mathbf{X}_{2}\right)$}

Simple Correlation Test shows that the regression equation formed is $\mathrm{Y}=0.920$ $+0.734 \mathrm{X} 2$. The simple regression equation above illustrates that the magnitude of the relationship of price variables to the buying decision is 0.734 . If the price variable is increased to 1 then the buying decision will be 1,654. If the price increase is done until the optimal condition or ideal that is on the scale of 5 on each instrument questionnaire it will obtain a score of 5 × $20=100$, it will increase the buying decision of $\mathrm{Y}=0.920+0.734(100)=74.32$ 
The $\mathrm{R}$ value of the correlation coefficient for $\mathrm{X}_{2}$ is 0.639 which indicates that there is a positive relationship between the price $\left(\mathrm{X}_{2}\right)$ with the buying decision (Y). The coefficient of determination $\left(\mathrm{R}^{2}\right)$ is 0.409 or $40.9 \%$. This means that the variant that occurs in the decision variable purchases $40.9 \%$ is determined by the variant that occurs in the variable price, while the remaining $59.1 \%$ is determined by other factors. Variable $\mathrm{X}_{2}$ (price) produces t count of 5.128 with a probability significance of 0.001 . It is known that ttable $(\mathrm{df}=40$, a $=0,05)$ is 1,684. Thus, it can be concluded that individually variable Price $\left(\mathrm{X}_{2}\right)$ relationship with variable Y (buying decision).

\section{Customer Perception of Promotion and Price Relations to Buying Decision}

Test Correlation and Coefficient of Determination the value of $r$ for $X_{1}$ and $X_{2}$ is 0.709 indicates that there is a relationship between customer perception between promotion $\left(\mathrm{X}_{1}\right)$ and price $\left(\mathrm{X}_{2}\right)$ together with buying decision $(\mathrm{Y})$. Based on the correlation coefficient interpretation, the correlation between promotion and price with buying decision is very strong. Moreover, the value of its determination coefficient $\mathrm{R}^{2}$ is 0,503 or $50,3 \%$, which means that variation of buying decision can be explained by other variation of promotion and price equal to $50,3 \%$, while the remaining $49.7 \%$ is determined by other factors.

From the multiple regression equation above, it can be seen that $\mathrm{Y}=0,229+$ $0,380 \mathrm{X}_{1}+0,527 \mathrm{X}_{2}$ the amount of independent variable related to buying decision is promotion 0,380 , price equals to 0,527 . If the promotion and price are jointly increased to 1 then the buying decision will be 1,391 . If the promotion and price increase is done together until the optimal or ideal condition is on the scale of 5 on each questionnaire instrument filled by the respondent, so that obtained a score of 5 x $40=200$ for $X_{1}$ and $X_{2}$ it will obtain an increase in buying decision of $\mathrm{Y}=0.229+0.380(200)+0.527(200)=$ 181,629 . 
F test is intended to know the relationship together (stimultant) independent variables (promotion and price) to the dependent variable (buying decision). From ANOVA test result or $\mathrm{F}$ test obtained $\mathrm{F}$ count equal to 18,686 with significance level equal to 0.000. It is known that Ftable is 3.232. From these results it can be seen that Fcount > Ftable and probability significance is less than 0.05 then $\mathrm{H} 1$ is accepted. Thus the regression model can be used to predict buying decision $(\mathrm{Y})$ or it is said that promotion variable $\left(\mathrm{X}_{1}\right)$ and price $\left(\mathrm{X}_{2}\right)$ together have significant relation to buying decision (Y).

From the result, some of jurnal explained that the reliability and validity of the scale was assessed in a pre-purchase situation, using exploratory and confirmatory analyses. All four value dimensions were found to help significantly in explaining attitude and behavior. The scale was also tested in a post-purchase situation and found to be both reliable and valid in this context as well. The PERVAL scale has a variety of pontenial applications and can serve as a framework for further empirical research in this import area (Sweeney \&Soutar, 2001).

In the journal (Frankie Markus, 2004) shows that Low-cost carriers (LCCs) were not only spares, but boosted by this massive downturn. Their lean business model offered a compelling alternative at time when passegers began looking for ways to avoid paying the high price NCs demanded in order to maintain their complex hub \& spoke systems. On continental travel routes, LCCs are able to deliver $80 \%$ of the service quality at less than $50 \%$ of the cost of NCs. Consequently. LCCs can-at least in the theory-tackle more than $70 \%$ of continental O\&Ds (in the US as well as in Europe), taking them far from their origins as niche business. However, for most intercontinental routes (as well as some continental ones) building demand in a hub remains as indispensable requirement.

Added by the journal written by (Akbar, Bisnis, \& Ciputra, 2016) on research of promotional relationship price to purchase decision; that price and promotion 
significantly influence to consumer purchase decision. Related with the journals, it is found that the research of promotion and price can affect the buying decision for customer to fly with Garuda Indonesia, because some of customer did not know the product and promotion from Garuda, such as frequent flyer, lowest price, and coorperation price.

The research about brand and promotion by (Keke, 2015) explain that the higher advertising, sales promotion, personal selling, public relations, direct marketing conducted by the company, then, the higher the level of awareness of the brand / product.

Strengthend by (Fahriza, 2016) Airlines present a wide ranging of services to facilitate customer convinience and comfort. Example call centre which is open 24 hours a day, seven days a week and provides a one stop information and reservation service. In recent time reservation service has been accompaniment by internet and mobile phone reservations with option making payment through the internet and mobile phone, Garuda frequent flyer and started valet service for business class.

The authors find that consumer expectations of both price and promotional activities should be considered in explaning consumer brand choice behavior. Specifically, the presence of a promotional deal when one is not expected or the absence of a promotional deal when one is expected may have a significant impact on consumers' brand choice. Finally, as in the case of price expectations, consumers' respons to promotion expectations is found to be asymmetrical in that losses loom larger than gains.(Manohar U. Kalwani and Chi Kin Yim, 1992).

\section{Conclusion}

Customer Perception of Promotion to purchase decision $\left(\mathrm{X}_{1}\right)$ variant, that happened in decision variable buy $34,6 \%$ determined by variant which happened in promotion variable. While the remaining $65.4 \%$ was determined 
by other factors. Test Result $\mathrm{t}$ that is equal to 4,486 with probability significance 0,001. Customer Perception of Price to buying decision $\left(\mathrm{X}_{2}\right)$ concluded that individually the variable is linked with variable $\mathrm{Y}$ (buying decision). Customer Perception of Promotion and Price related to buying decision. From these results it can be seen that Fcount $>$ Ftable and probability significance is less than 0,05 then $\mathrm{H} 1$ is accepted. Thus the regression model can be used to predict buying decision (Y) or it is said that promotion variable $\left(\mathrm{X}_{1}\right)$ and price $\left(\mathrm{X}_{2}\right)$ together have significant relation to buying decision $(\mathrm{Y})$

\section{References}

Akbar, A., Bisnis, F. M., \& Ciputra, U. (2016). HUBUNGAN HARGA DAN PROMOSI TERHADAP KEPUTUSAN, 1 .

Belch george \& Michael. (2009). Advertising and Promoting (8th ed.). New York: Mac Graw Hills.

David, F. (2011). Manajemen Strategi (12th ed.). Jakarta: Salemba Empat.

Diana PuspitaSari. (2006). THESIS PROMOSI.pdf.

Fahriza, B. (2016). SHOULD GARUDA INDONESIA JOIN THREE MAJOR AIRLINES ALLIANCES: STAR ALLIANCE ,. Jurnal Manajemen Bisnis Transportasi Dan Logistik, 3(1), 123-139.

Frankie Markus. (2004). Competition between network carriers and low-cost carriers-retreat battle or breakthrough to a new level of efficiency? Journal of Air Transport Management, 10(1), 15-21. https://doi.org/10.1016/j.jairtman.2003.10.008

Haryono, Wahyuni endang, D. (2016). LAYANAN TERHADAP KEPUASAN PELANGGAN PT . DMS TOUR AND TRAVEL. Jurnal Manajemen Bisnis Transportasi Dan Logistik, 2(2), 201-219.

Keke, Y. (2015). Komunikasi pemasaran terpadu terhadap brand awareness. Jurnal Manajemen Bisnis Transportasi Dan Logistik, 2(1), 172-186.

Kuntjoroadi, W., \& Safitri, N. (2009). Analisis Strategi Bersaing dalam Persaingan Usaha Penerbangan Komersial, 16, 45-52.

Linawati. (2015). SERVICE QUALITY. Jurnal Manajemen Bisnis Transportasi Dan Logistik, 2(1), 1-10.

Manohar U. Kalwani and Chi Kin Yim. (1992). Consumer Price and Promotion Expectations: An Experimental Study. Journal of Marketing Research, 29(1), 90-100. https://doi.org/DOI: 10.2307/3172495

Rahmawati, A. (2015). The Loyalty of Garuda Indonesia Customers to The Route of. Journal Management Transportasi Dan Logistik, 2(3), 297-312. 
Sanusi Anwar. (2011). Metodologi Penelitian Bisnis (5th ed.). Jakarta: Salemba Empat.

Shaw, S. (2011). Airline Marketing and Management (7th ed.). England: Ashgate Publishing.

Simamora Bilson. (2011). Memenangkan Pasar dengan Pemasaran Efektif dan Profitabel. Jakarta: Gramedia.

Singgih Santoso. (2004). Riset Pemasaran : Konsep dan Aplikasi dengan SPSS. Jakarta: ElexKomputindo.

Sugiyono. (2009). Metode Penelitian Kuantitatif Kualitatif dan R\&D (8th ed.). Bandung: Alfabeta.

Sweeney \&Soutar. (2001). Consumer perceived value: The development of a multiple item scale. Journal of Retailling, 77(22), 203-220. https://doi.org/https://doi.org/10.1016/S0022-4359(01)00041-0

Tjiptono Fandy. (2011). Management \&Strategi Merk. Jogjakarta: Andi.

Yoo, Donthu, L. (n.d.). Journal Academy Of Marketing of Science. An Examination of Selected Marketing Mix Elements and Brand Equity, $28(2)$, 195-211. Retrieved from https://doi.org/10.1177/0092070300282002 